\title{
Periodic Water Quality Monitiring of Surface Water in Korba District (C.G.) India
}

\author{
Madan Murari Vaishnav, Ramesh Janjala, Milan Hait, Pralhad Kanhaiyalal Rahangdale, and Shreni \\ Dewangan
}

\begin{abstract}
In this present attempt, surface water source of Korba district was studied for its know-how of its quality depletion over a period of time. During the analysis period, nine water sampling sites were selected, assigned from KDS-1-to KDS-9. Water samples were collected in pre-cleaned polyethylene and glass bottles of $1 \mathrm{~L}$ capacity from March-2010 to May-2010 (pre-monsoon). The collected water samples were analyzed as per the standard methods. Results were compared with standard values prescribed by BIS (1991) and WHO (2008) Except fluoride (1.17) and Dissolved Oxygen $\left(4.411 \mathrm{mgL}^{-1}\right)$, remaining all parameters were exceeded the desired limits. It was quite evident from the data that significant strong positive correlation was observed across Fe Vs TDS $(r=+0.961)$, Fe Vs Hardness $(r=0.961)$ Fe Vs phosphate $(r=0.961)$ Fe Vs Al $(r=0.961)$. On contrary, Do and TDS related negative high degree correlation $(r=-0.792)$. Calculated WQI revealed that entire water sources were highly polluted by the undesirable chemical constituents; hence water sources of the present study area might not be useful for any purposes.
\end{abstract}

Index Terms-Physico-chemical parameter, monitoring, statistical value, surface water and water quality.

\section{INTRODUCTION}

Clean water is basic and essential vital component for all healthy living organisms. Good quality of water is defined as absence of deleterious chemicals and microbes. In the universe, water is present as vapor (atmospheric moisture), liquid water (substance and ground water sources) and solid ice (in glacier) etc. Since ancient times, ground and rain water is being considered as fresh and safe water sources. Water also plays a significant role in science due to its universal solvent behavior. With the development of civilization, increasing industrialization and application of various fertilizers, pesticides, careless dumping and discharge of solids, liquids water sources the Earth planet is continuously getting polluted conducing various sources water unfit for use

Manuscript received June 10, 2015; revised October 23, 2015

Madan Murari Vaishnav is with the Department of Chemistry, Govt. G.B.College, Hardibazar, Korba, India (e-mail: drmmvaishnav@yahoo.co.in).

Ramesh Janjala was with the Department of Chemistry, C.M.D. Post Graduate College, Bilaspur, India (e-mail: jandhyala.ramesh@gmail.com).

Milan Hait is with the Department of Chemistry, Dr. C.V. Raman University, Kargi Road, Kota, Bilaspur, C.G., India (e-mail: haitmilan@gmail.com).

Pralhad Kanhaiyalal Rahangdale is with the Department of Chemistry, Bhawabhuti Mahavidyalaya, Amgaon, Gondia, India (e-mail: pkrahangdale@yahoo.co.in).

Shreni Dewangan is with the Department Public Health Engineering, State Government of Chhattisgarh, Champa, Janjgir, Champa, India (e-mail ashreni@rediffmail.com).
[1]. Heavy metals are one of the chief pollutants of water sources, which not only cause severe threat for human beings but also affect flora and fauna. The constituents of environment air, soil and food are also polluted by the heavy metallic elements that enter in water bodies through natural and artificial process. Although the trace amount of metallic elements are having biological importance, but theirs higher exposure [2] may create health problems like hypertension, iti-iti, cancer, kidney and liver disorder etc.

\section{MATERIALS AND METHODS}

\section{A. Study Area}

Korba district is situated in the northern half of Chhattisgarh state and spread at the confluence of river Hasdeo and Ahiran. The geographical location is $22^{\circ} 01^{\prime}$ North latitude and $82^{\circ} 08^{\prime}$ to $83^{\circ} 09^{\prime}$ East longitude. Topographically, study area is plane as well hilly area with height of 304.8 meter above mean sea level. The geo-morphological status of the district is lower Gandwana group [3]. Soils are red yellow with rich deposits of ferric oxide and laterite hard soil, which richest source of $\mathrm{Fe}$ and $\mathrm{Al}$. The investigation field received average rainfall $1506.7 \mathrm{~mm}$. The minimum temperature is $7^{\circ} \mathrm{C}$ in winter and higher temperature is $43^{\circ} \mathrm{C}$ in summer. Korba district is abundant with rich mineral reserves like bauxite, coal, etc. Coal based thermal power plant namely NTPC, BCPP, CSEB-east, OED-west; Lanco generated more than $21500 \mathrm{MW}$ of electricity. Owing to high power generation, thermal pollution is very high there by conducing water bodies of the study field polluted by the intrusion of undesirable substances. Therefore the present study will highlight and throw some light by scientific approach of assessing the water bodies of the study area (Fig. 1). In this present discussion, pre-monsoon 2010 (March to May 2010) was chosen as base for ongoing discussion of the results.

\section{B. Sampling and Preservations}

Water samples were collected in March, April and May (considered as pre-monsoon henceforth for ongoing discussion) selected site during pre-monsoon season of 2010 in pre-cleaned polythene and glass bottles of $1 \mathrm{~L}$ capacity for physico-chemical analysis and metallic analysis respectively. Collected samples were preserved as per standard method at $10^{\circ} \mathrm{C}$ and by adding of 1 or $2 \mathrm{~mL}$ conc. $\mathrm{HNO}_{3}$ to protect the precipitation and absorption of dissolved metallic ions.

\section{Brief Analytical Methods}

Physical parameters like Temp., pH, EC, turbidity, TDS, 
DO were analyzing at the sampling site by the portable analyzer kit (EL model no.172). Collected samples were brought to laboratory for the analysis of total hardness and total alkalinity by titration method. Anion parameter chloride was measured volumetrically by Argentometric method using potassium chromate as indicator. Fluoride was measured by ion-selective electrode. Sulphate was measured by Turbidity metric method, phosphate and nitrate were analyzed by spectrophotometric method. Demand parameters such as BOD were detected by Iodometric titration method, COD was estimated by dichromatic reflux method. Dissolved solids in terms of TS and TDS were detected by gravimetric method. Metallic elements were analyzed as per standard methods given in APHA, 2005 [4], Trivedi and Goel, 1984 [5] and N. Manivaskam, 2002 [6].

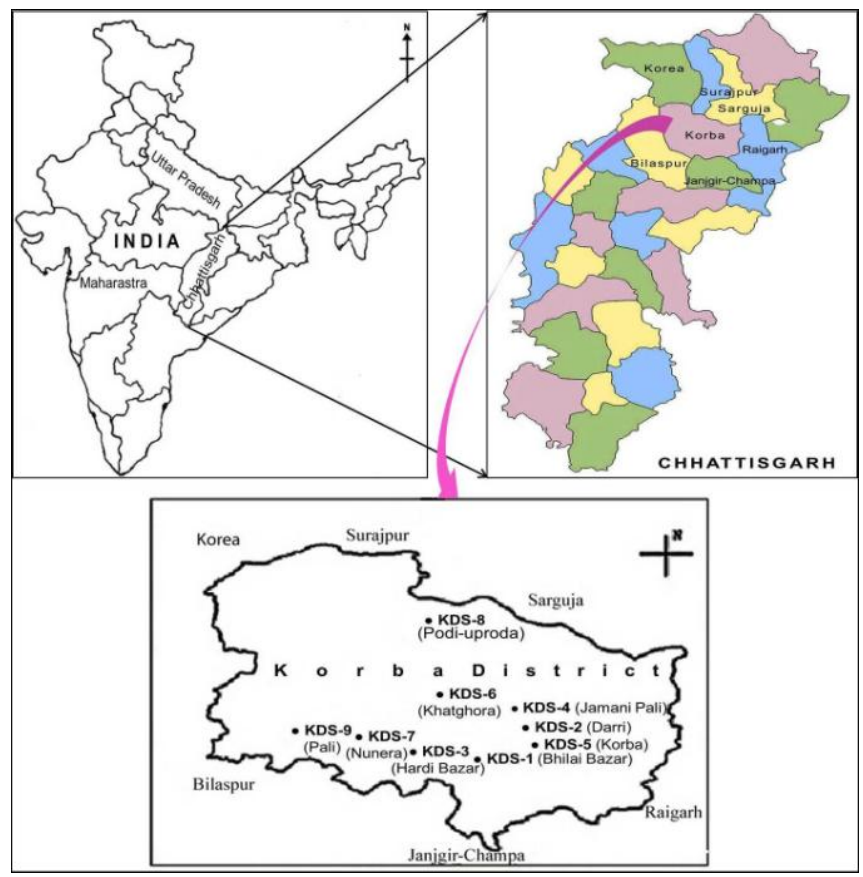

Fig. 1. Location of study area.

\section{RESUlTS AND DISCUSSION}

The obtained results of physico-chemical parameters and metallic elements were interpreted by statistical means in terms of mean, range, SD, SE, and \%CV as illustrated in Table I and correlation matrix was established between various parameters and is shown in Table II.

$\mathrm{P}^{\mathrm{H}}$ : $\mathrm{pH}$ of drinking water is an important index for determining the acidic or alkaline nature of water. When $\mathrm{pH}$ is below 4.0, creates acidic pollution resulting in destruction of most of the vertebrates and microorganism [7]. During pre-monsoon 2010, the average and range found to be 8.027 and 6.14 to 10.98 respectively. The range was quite beyond the standard range of 6.5 to 8.5 as per BIS (1991) [8] and WHO (2008) [9]. These results showed that the nature of water is varied from slightly acidic to strong base in nature.

Electrical Conductivity (EC): EC of water is depended on the presence of dissolved ions and high ionizable solids. The standard value of EC for potable as well as agricultural water is 750-2250 $\mathrm{SCm}^{-1}$ as per BIS (1991). If EC exceeds above $3000 \mathrm{Scm}^{-1}$; the germination of almost all crops would be affected and results in much reduced yields [10]. In study area, mean value for EC was found to be $1798.5 \mathrm{~cm}^{-1}$, while it was found ranging from 626 to $2404 \mathrm{Scm}^{-1}$. The max EC was reported at the sampling site KDS-2 in the month of May 2010. Owing to high atmospheric temp reduced the water level and increase the conc. of dissolved ions and mixing of domestic sewage in that particular water source.

Turbidity: Turbidity of water is the presence of suspended and partial dissolved material in water sources. Its standard value prescribed 5 -25 NTU as per standards of BIS (1991) [8] and WHO (2008) [9]. During the tenure of study period, its range was noted very wide from 38 NTU to 374 with 134.33 NTU as mean value. This obtained data was many folds greater than standard value. The value was found at the site no KDS-3 in the month of May to 2010 due to presence of high amount of suspended particles.

TDS: The fresh water had the value of TDS smaller than $1000 \mathrm{mg} \mathrm{L}^{-1}$ when it deviates from its standard value, water become blackish [11]. TDS is causing dissolved cation and anion species and bear a relationship with the electrical conductivity of water [12]. TDS was gravimetric analyzed, found the average value $1868.05 \mathrm{mg} \mathrm{L}^{-1}$ and ranging from $1651.6 \mathrm{mg} \mathrm{L}^{-1}$ to $2124 \mathrm{mg} \mathrm{L}^{-1}$. These statistical parameters showed, all water sources are highly polluted and for beyond from the acceptable ranges; $500 \mathrm{mg} \mathrm{L}^{-1}$ to $1500 \mathrm{mgL}^{-1}$ as BIS (1991) [8] and WHO (2008) [9].The high value was found at the sampling water KDS-3 in the month of May 2010 causing the increasing the cons of dissolved inorganic ions.

Total alkalinity: Chemical sources of total alkalinity in water are $\mathrm{CO}_{3}^{--}, \mathrm{HCO}_{3}^{-}, \mathrm{OH}^{-}, \mathrm{HSiO}_{3}^{-}, \mathrm{HPO}_{4}^{--}$and $\mathrm{HS}^{--}$The large quantity of alkalinity imparts bitter taste of water [13]. The desirable value for alkalinity is $200 \mathrm{mg} \mathrm{L}^{-1}$ while the excessive permissible level is $600 \mathrm{mgL}^{-1}$ as per water monitoring agency BIS (1991) and WHO (2008). During the study period, mean value was calculated to be 549.31 $\mathrm{mgL}^{-1}$ and it's ranging values varied from $466 \mathrm{mg} \mathrm{L}^{-1}$ to 711 $\mathrm{mg} \mathrm{L}^{-1}$. The high concentration was detected at the sampling spot KDS-3 in the month of March 2010 owing to the increased the concentration of chemical species that comes from various industrial sources.

Total Hardness: Water become hard when the cation and anion species of $\mathrm{Ca}^{++}, \mathrm{Mg}^{++} \mathrm{Sr}^{++}, \mathrm{Ba}^{++}, \mathrm{Fe}^{++}, \mathrm{Mn}^{++}, \mathrm{CO}_{3}^{--}, \mathrm{SO}_{4}^{--}$, $\mathrm{Cl}^{-}$ions are present. Extreme hard water produces krolithiasis, encephaly, parental mutatility cancer and cardiovascular disease [14]. In our study field, mean value obtained to be $671.66 \mathrm{mgL}^{-1}$ which was categorized as extreme hard water as per Sawyer and Mc-Worthy. The ranging value was reported from $498 \mathrm{mgL}^{-1}$ to $818.1 \mathrm{mgL}^{-1}$. The max. concentration was reported at the sampling site KDS-2 in the month of April 2010 , owing to discharge of liquid wastes with high cone of alkali and alkaline earth metals.

Fluoride: Fluoride is one of the minor constituents in natural waters but play vital in assessing the suitability of water for various purposes [15]. The slandered value prescribed for fluoride is $1.00 \mathrm{mgL}^{-1}$ to $1.50 \mathrm{mg}^{-1}$ as per BIS (1991) and WHO (2008). During the study period, Fluoride range was obtained from $0.39 \mathrm{mgL}^{-1}$ to $1.60 \mathrm{mgL}^{-1}$ with erythematic mean $1.17 \mathrm{mgL}^{-1}$. This average value was within the standard value. The max. concentration was found at the sampling site just above the marginal max. allowable limit of $1.50 \mathrm{mgL}^{-1}$. 
TABLE I: STATISTICAL PARAMETER OF WATER QUALITY OF PRE-MONSOON (MARCh-MAY)' 2010

\begin{tabular}{|c|c|c|c|c|c|c|c|c|}
\hline Parameters & MEAN & S.D & S.E & $\mathbf{\% C V}$ & MAX & MIN & RANGE & WHO Rec.2008 \\
\hline Temperature & 25.31 & 2.865 & 0.106 & 0.1132 & KDS-9, May & KDS-5, Mar & $32.51-21.22$ & $27-28$ \\
\hline PH & 8.027 & 1.233 & 0.046 & 0.1536 & KDS-5, Mar & KDS-2, Mar & $10.98-6.14$ & $6.5-8.5$ \\
\hline Conductivity & 1798.5 & 536.45 & 19.869 & 0.2982 & KDS-2, May & KDS-8, Mar & $2404-626$ & 1000 \\
\hline Turbidity & 134.33 & 91.06 & 3.37 & 0.677 & KDS-3, May & KDS-7, May & $374-38$ & 5 NTU \\
\hline TS & 2189 & 137.727 & 5.101 & 0.0629 & KDS-4, May & KDS-6, Mar & $2390-1881.5$ & $* * *$ \\
\hline TDS & 1868.05 & 124.88 & 4.625 & 0.0669 & KDS-3, May & KDS-1, Mar & $2124-1651.6$ & 1000 \\
\hline TSS & 321.71 & 116.846 & 4.328 & 0.3632 & KDS-8, May & KDS-9, Mar & $550.1-127.67$ & $* * *$ \\
\hline Alkalinity & 549.51 & 66.75 & 2.472 & 0.1215 & KDS-3, Mar & KDS-2, Mar & $711-466$ & $* * *$ \\
\hline Total Hardness & 671.66 & 84.57 & 3.132 & 0.1259 & KDS-2, Apr & KDS-8, Mar & $818.1-498$ & 500 \\
\hline Chloride & 841.77 & 224.75 & 8.324 & 0.267 & KDS-5, Apr & KDS-4,Mar & $1281-63.11$ & $200-1000$ \\
\hline Fluoride & 1.17 & 0.338 & 0.013 & 0.2888 & KDS-2, May & KDS-7, Apr & $1.60-0.39$ & 1.5 \\
\hline Sulphate & 289.26 & 69.95 & 2.591 & 0.2418 & KDS-3, May & KDS-7, Mar & $4111-171.61$ & 250 \\
\hline D.O & 4.411 & 1.065 & 0.039 & 0.2414 & KDS-7, Mar & KDS-3, May & $5.97-3.01$ & \\
\hline BOD & 24.04 & 7.32 & 0.271 & 0.3044 & KDS-4, May & KDS-8, Mar & $41.04-8.11$ & 5 \\
\hline COD & 58.05 & 43.06 & 1.595 & 0.7417 & KDS-9, May & KDS-8, Apr & $179.2-8.55$ & 5 \\
\hline Nitrate & 60.82 & 27.16 & 1.006 & 0.4465 & KDS-5, Mar & KDS-2, May & $114.5-31.51$ & 10 \\
\hline Phosphate & 0.274 & 0.188 & 0.007 & 0.6861 & KDS-1, May & KDS-7, May & $0.539-0.013$ & 45 \\
\hline Al & 0.532 & 0.794 & 0.029 & 1.4924 & KDS-3, May & KDS-8, Apr & $2.56-0.06$ & $0.01-0.05$ \\
\hline Iron & 0.8166 & 1.415 & 0.052 & 1.7327 & KDS-3, May & KDS-5, May & $4.91-0.02$ & 0.03 \\
\hline
\end{tabular}

TABLE II: CORRELATION MATRIX OF PRE-MONSOON (MARCH-MAY)' 2010

\begin{tabular}{|c|c|c|c|c|c|c|c|c|c|c|c|c|c|c|c|c|c|c|c|}
\hline & Temp. & PH & Cond. & TDS & TSS & Turb. & TS & Alk. & T.H & Cl- & F- & SO42- & D.O & COD & BOD & NO3- & PO43- & Al & $\mathbf{F e}$ \\
\hline Temp. & 1.000 & & & & & & & & & & & & & & & & & & \\
\hline PH & -0.126 & 1.000 & & & & & & & & & & & & & & & & & \\
\hline Cond. & -0.380 & -0.200 & 1.000 & & & & & & & & & & & & & & & & \\
\hline TDS & 0.446 & -0.239 & 0.053 & 1.000 & & & & & & & & & & & & & & & \\
\hline TSS & -0.306 & -0.003 & -0.163 & -0.783 & 1.000 & & & & & & & & & & & & & & \\
\hline Turb. & 0.371 & 0.004 & 0.323 & -0.404 & -0.404 & 1.000 & & & & & & & & & & & & & \\
\hline TS & 0.336 & -0.389 & -0.118 & 0.592 & -0.013 & 0.592 & 1.000 & & & & & & & & & & & & \\
\hline Alk. & 0.441 & 0.243 & 0.134 & -0.262 & -0.493 & 0.859 & 0.237 & 1.000 & & & & & & & & & & & \\
\hline T.H & -0.555 & -0.436 & 0.711 & -0.260 & -0.349 & -0.097 & -0.187 & -0.260 & 1.000 & & & & & & & & & & \\
\hline Cl- & -0.059 & 0.709 & 0.392 & -0.093 & -0.285 & 0.454 & -0.327 & 0.630 & -0.093 & 1.000 & & & & & & & & & \\
\hline F- & 0.335 & -0.314 & 0.530 & 0.243 & -0.224 & 0.436 & 0.210 & 0.210 & 0.243 & 243.00 & 1.000 & & & & & & & & \\
\hline SO42- & 0.300 & 0.210 & 0.588 & 0.698 & $\begin{array}{r}-0.429 \\
\end{array}$ & 0.725 & -0.010 & 0.728 & 0.698 & 0.787 & 0.698 & 1.000 & & & & & & & \\
\hline D.o & -0.071 & -0.033 & -0.666 & -0.792 & 0.311 & -0.699 & -0.322 & -0.398 & -0.792 & -0.512 & -0.776 & -0.792 & 1.000 & & & & & & \\
\hline COD & 0.592 & -0.011 & -0.227 & -0.018 & -0.752 & -0.030 & -0.107 & 0.101 & -0.018 & -0.015 & 0.219 & 0.149 & -0.018 & 1.000 & & & & & \\
\hline BOD & 0.333 & -0.564 & 0.574 & 0.232 & -0.508 & 0.637 & 0.446 & 0.388 & 0.232 & -0.038 & 0.541 & 0.497 & -0.585 & 0.232 & 1.000 & & & & \\
\hline NO3- & 0.111 & 0.765 & 0.160 & -0.100 & -0.402 & 0.447 & -0.250 & 0.681 & -0.100 & 0.950 & 0.152 & 0.706 & -0.393 & 0.179 & -0.100 & 1.000 & & & \\
\hline PO43- & 0.191 & 0.575 & 0.140 & 0.641 & 0.053 & 0.396 & -0.167 & 0.450 & 0.641 & 0.730 & 0.417 & 0.693 & -0.542 & -0.096 & -0.107 & 0.641 & 1.000 & & \\
\hline $\mathrm{Al}$ & 0.312 & -0.121 & 0.236 & 0.370 & -0.295 & 0.913 & 0.518 & 0.818 & 0.370 & 0.299 & 0.302 & 0.583 & -0.515 & -0.168 & 0.582 & 0.250 & 0.370 & 1.000 & \\
\hline $\mathrm{Fe}$ & 0.368 & -0.01 & 0.031 & 0.961 & -0.33 & 0.868 & 0.525 & 0.837 & 0.961 & 0.250 & 0.075 & 0.448 & -0.35 & -0.101 & 0.488 & 0.263 & 0.961 & 0.961 & 1.000 \\
\hline
\end{tabular}

Chloride: The chief sources of chloride in water are agricultural fertilizer, industrial and domestic sewages beside chloride rich rocks [16]. As per the analytical study, the mean value was obtained to be $841.77 \mathrm{mgL}^{-1}$ and min. value was reported to be $63.11 \mathrm{mg} \mathrm{L}^{-1}$ to max value of $1281 \mathrm{mgL}^{-1} 1$. The high value was found at sampling site KDS-5 (April-2010) due to discharging of domestic and municipal wastes into the water sources.

Sulphate: Sulphate ion may be sourced by industrial and anthropogenic addition in the form of sulphate fertilizers. High concentration may cause laxative effect on human system [17]. In study field, the mean value was found to be $289.26 \mathrm{mgL}^{-1}$ crossed the desirable limit $200 \mathrm{mgL}^{-1}$ while it's range spread from $171.61 \mathrm{mgL}^{-1}$ to $411 \mathrm{mg} \mathrm{L}^{-1}$ as max values. The high values was slightly above the excessive permissible level: $400 \mathrm{mgL}^{-1}$ (BIS) that was found at sampling location KDS-3 during May (2010) due to intrusion of residue of agricultural fertilizer through surface runoffs.

Nitrate: The high concentration of nitrate in drinking water is toxic, causes blue baby disease, methamoglobinemia in children and gastric carcinomas [18]. In investigation field, the min conc. of nitrate ion was analyzed as $31.51 \mathrm{mgL}^{-1}$ and max conc. was found to be $114.5 \mathrm{mgL}^{-1}$ found at sampling site KDS-5 during March (2010). The average value was calculated to be $60.82 \mathrm{mgL}^{-1}$, which was above the threshold value of 45 and $50 \mathrm{mgL}^{-1}$ as set by BIS (1991) [8] and WHO (2008) [9].

Phosphate: Phosphate is main constituents of fertilizers and different kinds of rocks. In the study field the mean value $0.274 \mathrm{mgL}^{-1}$ was observed beside its range value of $0.013 \mathrm{mg}$ 
$\mathrm{L}^{-1}$ to $0.539 \mathrm{mg} \mathrm{L}^{-1}$. The high concentration of phosphate was reported at the sampling site KDS-1during the month of May-2010.

Dissolved Oxygen (DO): Plays a vital role for aquatic bio-system. The standard value of DO for survival of aquatic life is $5 \mathrm{mgL}^{-1}$ as per WHO (2008) standard [9]. In study field the dissolved oxygen was calculated as average value 4.411 $\mathrm{mgL}^{-1}$ which is slightly lower than required value. The ranging value found from $3.01 \mathrm{mgL}^{-1}$ to $5.97 \mathrm{mgL}^{-1}$. The high value was found at the sampling location KDS-7 during March-2010 indicating that water sources were deficient of dissolved oxygen and unfit for aquatic life.

BOD: Biological oxygen demand of water is depended on the presence of aquatic wastes and toxic materials. During, the mean value was found to be $24.04 \mathrm{mgL}^{-1}$ which is six fold higher than the WHO (2008) limit. The minimum conc. found to be $8.11 \mathrm{mg} \mathrm{L}^{-1}$ and max concentration was analyzed as $41.04 \mathrm{mg} \mathrm{L}^{-1}$ at the sampling site KDS-4 in the month of May 2010 , which could be attributed to the disposal of organic waste in that water sources.

COD: In study area, mean value of $58.05 \mathrm{mgL}^{-1} 1$ was found which is five times greater than the standard value: 10 $\mathrm{mgL}^{-1}$ as per WHO (2008) [9] where as it was found ranging from $8.55 \mathrm{mgL}^{-1}$ to $179.2 \mathrm{mgL}^{-1}$. The max value was seen at the sampling point KDS-9 in the month of May 2010, which could be attributed to the mixing of municipal wastes in water source.

Metallic Elements: We have selected four elements namely aluminum, iron, mercury, and zinc that are environmentally significant for assignment. During the monitoring period, the average value for $\mathrm{Al}$ and $\mathrm{Fe}$ were calculated to be 0.532 and $0.8166 \mathrm{mgL}^{-1}$ respectively. The rang found to be between 0.06 $\mathrm{mgL}^{-1}$ and $2.56 \mathrm{mgL}^{-1}$ for Al while $0.02 \mathrm{mgL}^{-1}$ to $4.91 \mathrm{mgL}^{-1}$ for iron respectively .The high conc. of $\mathrm{Al}$ and $\mathrm{Fe}$ were observed at the sampling site KDS-3 in the month of May 2010 owing to lithological erosion.

Correlation Analysis: To observe the correlation between different physicochemical quality, which shown in correlation matrix form, Total 190 relations were established, in which 108 were positive relations while remaining were categorized as negative relations. The higher positive significant value was found $\mathrm{Fe}$ Vs hardness, Fe Vs phosphate Fe Vs TDS respectively. This was self-explanatory that the iron compound was greatly influence the total hardness and total dissolved solids orderly. Aluminum compounds were also observed to a great extent of positive value of 0.913 and 0.818 with turbidity and total alkalinity. Nitrate was also found to be positive correlated with chloride $r=0.950$. Al and Fe were established positive relation with total alkalinity with $r$ value of $r=0.818$ and 0.837 respectively. It means that the high concentration of Aluminum and iron compounds were main cause of total alkalinity. Metallic elements are naturally correlated together by the positive significance such as iron and aluminum with $r$ value of 0.961 indicating that the source of both metallic elements in water bodies was same. High relative correlation was also found between DO and TDS ( $r=$ -0. 792). DO also formed negative relation with hardness, fluoride and sulphate with $r$ value $-0.792,-0.776$, and -0.792 orderly. It showed that the $\mathrm{F}^{-}, \mathrm{SO}_{4}{ }^{--}$and hardness components found decreased dissolved oxygen in water, making it unfit for aquatic environments.

$\% \mathrm{CV}$ : Percentage of correlation variances were calculated for all selected water quality parameters. It was obtained from 66.85 for TDS to 173.2 for Fe. This calculation suggested that the value of TDS was changed among all selected sources. While Fe concentration observed high variance among other WQP's, indicated the iron concentration are high changes place to place.

\section{CONCLUSION}

On the basis of above observation and its subsequent results \& discussion, it was very conspicuous that the maximum concentrations of physico-chemical parameters were crossed the maximum permissible level. One of selected metallic elements $\mathrm{Fe}$ and $\mathrm{Al}$ were reported far above the desired value. Furthermore it can also be concluded that water sources of the present study area got polluted at high degree of unacceptability with the std. values.

\section{ACKNOWLEDGMENT}

The authors are grateful to DIRECTOR of ANACON laboratory Nagpur for metallic analysis. Also sincerely thank to Dr. MAN SING, Head and Professor of department of Chemistry, Gandhi University, Gandhi Nagar, Gujarat, India for his continues encouragement and suggestions time to time.

\section{REFERENCES}

[1] M. L. Sundar and M. K. Saseetharan, "Ground water quality in Coimbatore, Tamil Nadu along Noyyal River,” J. Environ. Sci. Egg., vol. 50 , no. 3 , pp. 187-190, 2008.

[2] G. P. Jeyanthi and G. Shanthi, "Remediation of lead from lead electroplating industrial effluent using sago waste," J. Environ. Sci. Egg., vol. 49, no. 1, pp. 13-16, 2007.

[3] K. Tripathi and P. Chandrakar, Chhattisgarh Atlas, Sharda Publication, Bilaspur (CG), pp. 20-25.

[4] APHA, Standard Methods for Examination of Water and Waste Water, $21^{\text {th }}$ Ed., American Public Health Association, 2005.

[5] N. Manivaskam, Physicochemical Examination of water Sewage and Industrial Effluent, Pragti Prakashan, Meerut, 2002.

[6] R. K. Trivedi and P. K. Goel, Chemical and Biological Methods for Water Pollution Studies, Environmental Publication Karad, 1984.

[7] G. S. Rao and G. N. Rao, "Study of ground water quality in greater Visakhapatnam City, A. P. India,” J. Environ. Sci. Engg., vol. 52, no. 2, pp. 137-146, 2010.

[8] BIS, Indian Standard Drinking Water Specification (First Revision) IS:10500, Bureau of Indian Standard, New Delhi, 1991

[9] WHO, Guideline for drinking Water Quality, vol. 1, World-Health Organization, Geneva, 2008.

[10] K. Jothivenkatachalam and A. Nithya, "Assessment of ground water quality index around Nomakkal district, Tamilnadu, India," Poll. Res., vol. 30, no. 1, pp. 37-43, 2011.

[11] A. R. Freeze and J. A. Cherry, Ground Water, Prentice Hall, New Jersey, 1979, pp. 84-307.

[12] N. Kapil and K. G. Bhattacharyya, "Bio-monthly varitaion of wetland water quality: A case study with deeper bell, Assam, India," in Proc. Sixteenth National Symposium of Envitonment, Haryana, India, pp. 166-170, 2008.

[13] D. Garg, S. Goel, S. Chaturvedi, and R. V. Sing, "Positional survey of ground water quality of Bharatpur area during the monsoon season," $J$. Curr. Sci., vol. 10, pp. 131-136, 2007.

[14] WHO, Guideline for Drinking Water Quality, vol. 2, Geneva, 2008

[15] N. Vardarajan and B. K. Purandara, "Fluoride contamination in ground wter of malaprabha subbasin," J. Environ. Sci. Engg., vol. 50, no. 2, pp. 121-126, 2008.

[16] J. Sirajudden and A. A. Jameel, "Risk assessment of physicochemical contaminates in ground water of Pettavaithalai area, Tiruchirappalli, Tamil Nadu, India," Environ. Monit. Asses., vol. 123, pp. 299-312, 2006. 
[17] T. Subramani, L. Elango, and S. R. Damodarasamy, "Ground water quality and its sutability for drinking and agricultural use in Chithar River basin, Tamilnadu, India," Environ. Geol., vol. 47, pp. 1099-1110, 2005.

[18] B. S. Shankar, N. Balasubramanya, and M. T. M. Reddy, "Hydrochemical assessment of the pollutants in ground waters of Vrishabhavati velly basin in Bangalore (India)," J. Environ Sci. Engg., vol. 50, no. 2, pp. 97-102, 2008.

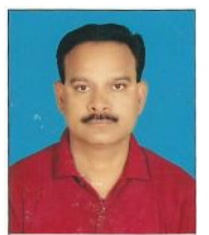

Madan Murari Vaishnav was born in Bilaspur district of Chhattisgarh State, India on January 30, 1964. He had secondary school education from Frastepur, Bilaspur, India. Then he proceeded to Guru Ghasidas University, Bilaspur where he obtained his BSc. $2^{\text {nd }}$ division in 1985 , the MSc. (organic chemistry) in 1987 and the Ph.D. in phytochemistry in 1992 . He is associate professor and HOD, Department of Chemistry, Govt. G.B.College, Hardibazar, Korba, C.G.,India. His area of specialization is phytochemistry and water pollution. He has more than 22 years teaching and research experience. He is a member of Journal of Indian Chemical Society. He has published six books in state level publication and 41 research paper in national and international Journal.

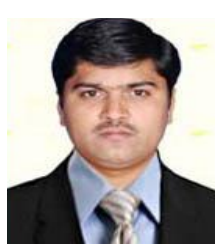

Ramesh Janjala was born April 5, 1981 in the Coastal Andhra Pradesh state of India, and had a schooling and graduation in the same place. He completed his M.Sc. with organic chemistry in the year 2005 and the $\mathrm{Ph} . \mathrm{D}$ in environmental chemistry from Guru Ghasidas University, Bilaspur, C.G. India in 2014. He has published 6 papers in international journal.

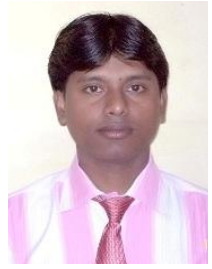

Milan Hait was born on July 2, 1987 in Purba Medinipur, West Bengal. He obtained his M.Sc. in chemistry in 2006 from the Guru Ghasidas University, Bilaspur, C.G. India; the M.Phil and the PhD (contd.) from Dr. C.V. Raman University, Kota, Bilaspur, C.G. India. $\mathrm{He}$ joined as an assistant professor of the University in 2011. He has published 17 papers in international journal.

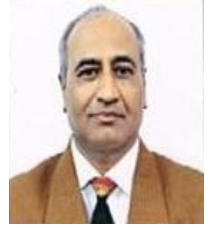

Pralhad Kanhaiyalal Rahangdale was born in Maharashtra State, India on October 24, 1962. He obtained the Ph.D. in organic chemistry in August, 1996 from RTM Nagpur University, Nagpur. He is associate professor \& HOD, Department of Chemistry, Bhawabhuti Mahavidyalaya, Amgaon-441902, India. His area of specialization is organic chemistry, polymer chemistry, synthetic and ion exchange chemistry, photo chemistry \& activated carbon chemistry. He has more than 25 years teaching and 24 years research experience. He has published 32 research papers in national and international Journal.

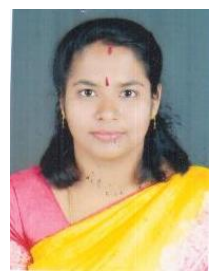

Shreni Dewangan was born in Korba district of Chhattisgarh State, India on April 20, 1980. She had secondary school education from Korba, Chhattisgarh, India. Then she proceeded to Government P. G. College, affiliated to Guru Ghasidas University, Bilaspur where she obtained her BSc. $1^{\text {st }}$ division in 2001, the MSc. (organic chemistry) in 2004 and the Ph.D. in chemistry in 2013. Presently, she is working as a chemist in Public Health Engineering Department, Division of State Government of Chhattisgarh, posted at Champa, District Janjgir - Champa, C.G., India. Her area of specialization is drinking water quality and water pollution. She is an associate member in International Congress of Environmental Research. She had published 11 research paper in National and International Journals 